\section{Inner Poverty: a setting of Peter Zumthor's Brother Klaus Field Chapel}

Ross Jenner

From a distance, Zumthor's Feldkapelle at Wachendorf appears as a slab, stele or dolmen: an erect monolith of unlikely interiority. ${ }^{1}$ The object's blurred, paradoxically diaphanous appearance derives from its being of a substance with the mud of the fields, of the same sand and gravel as its site and mixed there with white cement, sticking making to locality. ${ }^{2}$ On approach, it yields, via a pivoting triangular door, a blackened interior cast on tree trunks, open to the sky, wet underfoot, spangled with the glazed apertures of its former form-ties and reeking like a chimney of smoke. ${ }^{3}$

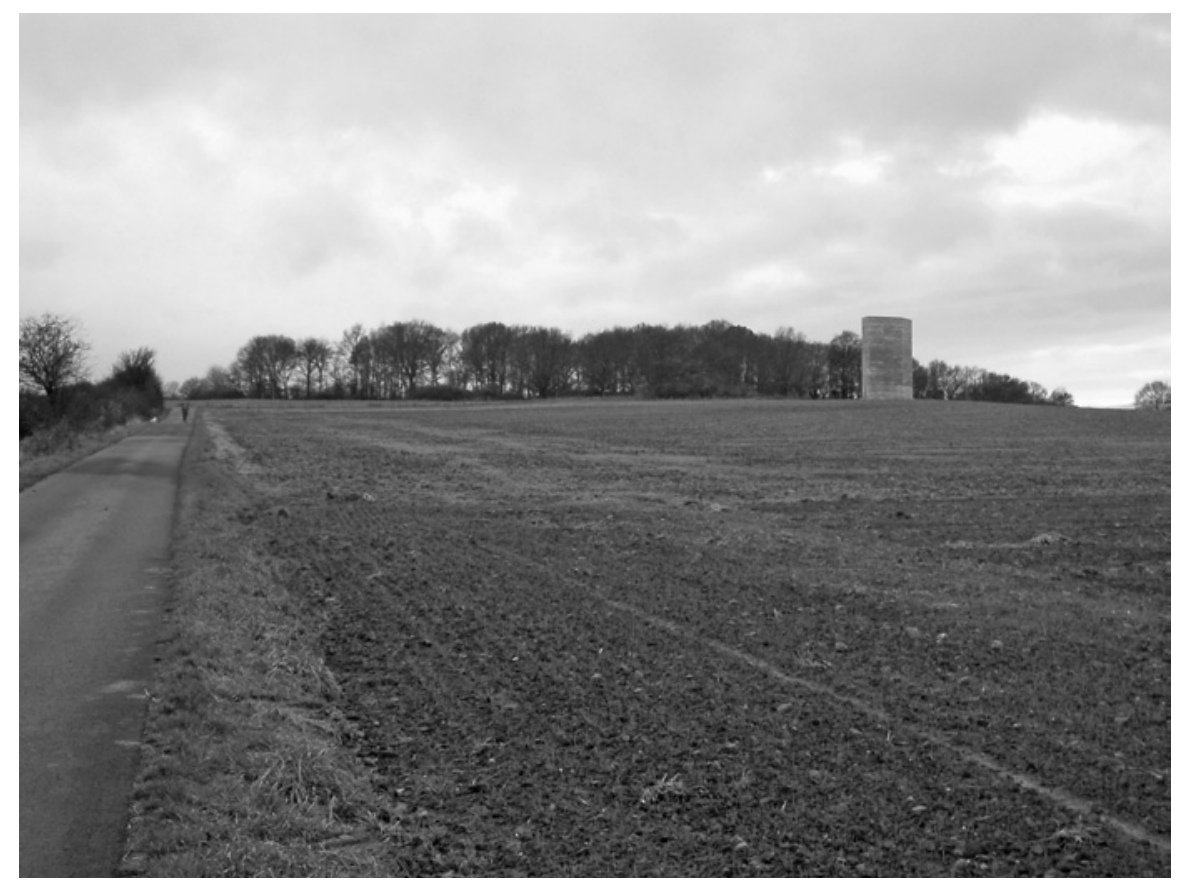

View from distance approaching on foot through fields (Photo: author)

In the working of concrete - a material both amorphous and deemed devoid of inner life - and in the forming of an interior as burnt-out trace, this work is as much about matter and making as it is about form and content. ${ }^{4}$ In memory of the hermit, Niklaus, in the refusal to transcend from material to image, (that is, to stand above matter) in depriving the work of the completion which is form, its poverty is its potential.

\section{Concrete}

Concrete, the essential ingredient at Wachendorf, is still regarded as the simulation of a material: stone. ${ }^{5}$ By imprint it can simulate other forms but it has none of its own, except as a mixed, messy mass, a paste or dough kneaded then clotted. Ferro-cement is scientifically conceived, but mud-like. The origins of the French (thence German) word for concrete, béton, point to nothing promising. In historian Peter Collins' account, it derives from betum, Old French for "a mass of rubbish" (2004: 21). ${ }^{6}$ According to Larousse, betum derives from the Latin bitumen:
1 Thanks are due to Peter Zumthor for an interview in Autumn 2008, to Ted McCoy, Leonhard Ott, Joseph Rykwert and Tina Engels-Schwarzpaul for their help. A University of Auckland Faculty Research Grant has also to be acknowledged.

2 Such localisation of concrete has not been thoroughly researched. It is clear, however, that Perret used regional aggregates to relate his concrete to the local; Wright's Los Angeles "textile block" houses were made from the materials of the sites in an attempt to capture an indigenous colour and texture. The dark reddish-brown hue of I. M. Pei's National Center for Atmospheric Research, Boulder. Colorado, is made to match the range of the Rocky Mountains before which it is set with sand ground from the nearby quarry and the surface bush-hammered like eroded rock. See Legault (2006: 51-52).

3 For a full description of the construction of the chapel, see Rossmann (2008: 12-14) and Baglione (2007: 142-153).

4 In Zumthor's words: "I think materials somehow stand above form. Artists such as Beuys have used materials in a more essential, basic way than many contemporary architects. There is an unwritten code which defines the meanings of materials in particular contexts and in my buildings I like to work with that." (1996:64)

5 Ostler (1995) and Cohen (2006), for example, still feel obliged to reference concrete to stone.

6 Cohen, however, claims that the late eighteenth-century experiments of the labourer François Cointereaux, "with adobe cast in a type of wooden form called a 'bétum' ... provided the etymology for 'béton' in French" (Cohen and Moeller 2006: 22). 
Left: Site model moulded in plasticine (Courtesy Architekturbüro Peter Zumthor). Right: Ground and polished concrete on podium to left of entry (Photo: author)
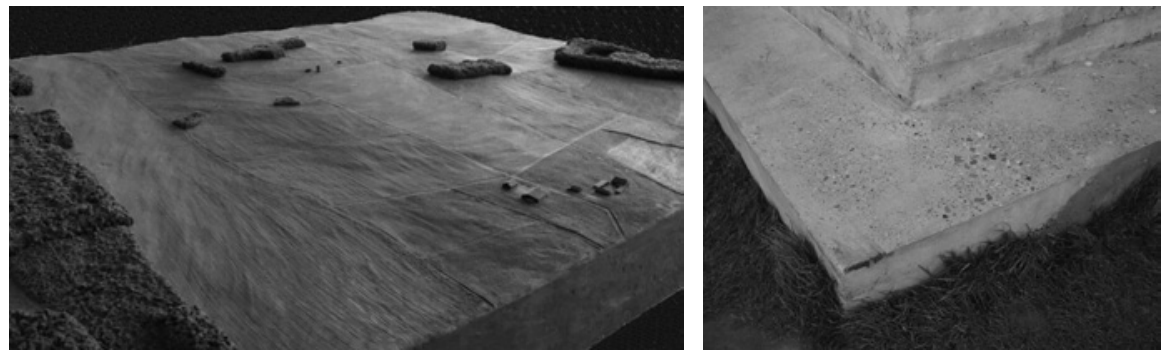

bitumen, pitch and asphalt: sticky things used in sealing and preserving. Concrete demands processes of cutting, breaking, crushing, mashing, milling, grinding and pulverising into aggregates, sands, and fired powders, which when hydrated as pastes and mixed, collect, coagulate, thicken, curdle and set, turning from plastic to solid. ${ }^{7}$ The name of its relative, "mortar", derives from grinding to paste (with pestle and mortarium) but implies dead as opposed to living stone. Lime, the chalky mineral used in making mortar derives from Old English lim "sticky substance", related to German Leim, from *(s)lei- "slime, slimy, sticky", related to loam. In a sense, concrete resembles stone but, being ersatz, can never equal it. Granular, it lacks its grain (even if all stone were once plastic). Only when the moulded is hammered or, as on the podium to the left of the entry at Wachendorf, polished into a seat, can a richness or inner life of the material be suggested.

7 In Vitruvius, De architectura, II, iv, the term caementum (from the verb caedo, to cut into pieces) indicated the scrap stone used to make concrete. Caementum became cementum in vulgar Latin, keeping the meaning of scrap stone. In the later Middle Ages it would assume the meaning, in the Italian term cemento, of the whole conglomerate that is contemporary concrete. Only at the end of the eighteenth century did the term "cement" assume its current meaning, while the conglomerate was definitively assigned the term "concrete". In English, the OED cites G. Godwin, 1836, on "concrete" from Trans. Inst. Brit. Archit. 12: "The generic term dates from the period when its use became general and frequent, probably no longer than 15 or 20 years ago." See Collins (2004: 36).

8 Here Benjamin wrote "For just like any good car, whose every part, even the bodywork, obeys the needs above all of the engine, Klee's figures too seem to have been designed on the drawing board, and even in their general expression they obey the laws of their interior. Their interior [dem Innern], rather than their inwardness [der Innerlichkeit]." (Benjamin 1982: 215-16,1996: 733 - translation modified)

9 For example, Benjamin (1982: 220, 1999 157) quotes Mayer: "Iron inspired a certain distrust just because it was not immediately furnished by nature, but instead had to be artificially prepared as a building material. This distrust is only a special application of that general sentiment of the Renaissance to which Leon Battista Alberti [1966: 239, 1988 83] gives expression."

10 Joray refers to the Swiss writer CharlesFerdinand Ramuz (1878-1947).
With the arrival of modernity in architecture, the interior Walter Benjamin found lost was replaced by a notion of design from the inner workings of things (machine, mind, material, matter). Glass, the main focus in his essay "Experience and Poverty", 8 embodied the sense of calculation, hardness, coldness and loss of "inwardness" - evident also in other modern materials like steel and concrete. All three undergo a plastic phase and are, in a sense, artificial, synthetic, and initially distrusted. ${ }^{9}$

Nevertheless, as emblem of modernity, empty and without "inwardness", concrete excels in its capacity to receive imprints. Frank Lloyd Wright's remarks on the meaning of concrete reflect its generally-held sense of baseness. It is "supine, and sets as the fool, whose matrix receives it, wills". It is "mongrel, servile" and "one of the insensate brute materials that is used to imitate others" - "it has neither song nor story". However, Wright continued, "surely here, to the creative mind, is temptation. Temptation to rescue so honest a material from degradation.” Therefore,

its form is a matter of this process of casting rather than a matter of anything at all derived from its own nature. Because it is thus, universally, at the mercy of demoralizing extraneous influences, it is difficult to say what is "concrete" form and what is not. $(1975,208)$

On the use of concrete in art, the Swiss, Marcel Joray, argued for transcendence: concrete is, in itself, "neither noble nor base ... Only through inspiration can concrete be given a soul. Concrete might rather be considered as antipoetic, but 'poetry is only made with the antipoetic', according to Ramuz. The act of creation transcends the material." (1977: 13) ${ }^{10}$ Historian, Adrian Forty argues (along Wright's lines): concrete "is not a material, it is a process" (2006: 35). Rejecting the expectation that it should have "its proper form", he adds "uncertainty, indecision, and conflict are normal, and, indeed, structural" to concrete (35) and "[a]11 that characterises the aesthetics of concrete is confusion and uncertainty" (37). 
There is, however, one property, which seems too blatant to bother about today, but upon which Wright (one of the last to remember it) did not fail to insist - the "essential difference" discovered in "the plasticity of the material itself":

I should say that in this plasticity of concrete lies its aesthetic value. As an artificial stone, concrete has no great, certainly no independent, aesthetic value. As a plastic material - eventually becoming stone-like in character - there lives in it a great aesthetic property, as yet inadequately expressed. (1975: 209)

The plasticity of moulding and modeling, in architectural thinking, must be understood in relation to elementary means of acting on and with materials, and in making relative to their properties as they concern human life. Save its technical side, however, this area is little theorised. There are the millennia of behaviour with materials, recovered by anthropology and living-on in language, and there are a few words by Zumthor himself, even if not specific. For example:

To me, there is something revealing about the work of Joseph Beuys and some of the artists of the Arte Povera group. What impresses me is the precise and sensuous way they use materials. It seems anchored in an ancient, elemental knowledge about man's use of materials, and at the same time to expose the very essence of these materials, which is beyond all culturally conveyed meaning. $(2006: 8-10)^{11}$

Lest it seem here that Zumthor revert to any simple essentialism, it could be noted that the 'poverty' of Arte Povera lies in stripping away preconceptions regarding materials and form in attacking the powers of hierarchical structures, the market place, the corporate mentality and cultural institutions in general. Moreover, the anthropologist André Leroi-Gourhan in his critique of the "culturalist" point of view, posited with regard to ancient knowledge of materials, the notion of a "technical tendency" independent of the particular cultural milieu in which it is concretised. ${ }^{12}$

The term "plastic" is a comparatively recent revival. In 1879, Gottfried Semper observed that "[t]he Greek word plastic (Plastik)" was used only for "figurative representation", was "not in general use and hence sound[ed] affected" (1879: 1). In Semper's schema, plastic "referred to the process of forming", in particular to clay (kéramos), the "material basis" of ceramics - but it also encompassed metal and glass. Concrete had scarcely entered architectural discourse at this stage. Moulding, a "mode of operating" (Rykwert 1990: 42), ${ }^{13}$ concerned what is "[s]oft, malleable (plastic), capable of being hardened, easily shaped and formed, and retaining a given form when hardened" (Semper 1879: 9). Leroi-Gourhan noted of "plastic solids" in their primary state: "[t]heir common characteristic is to be able to pass from an almost fluid to a solid or consolidated state. One cannot assign them categories based on their composition (mineral, horn or metal)." He proposed three groups:

those which are and remain powdery like the earth; those which by mixing with water become pastes and by heating pass into a stable state like clays; those which by mixing become semi fluids and harden by drying. These are, respectively, plastics of weak cohesion, plastics proper and agglutinating plastics. (1943: 214-15)

Of the treatment of clay he proposed, in turn, three modes: modelling, moulding and turning (1943: 221-243). He did not, of course, include concrete in these classifications.

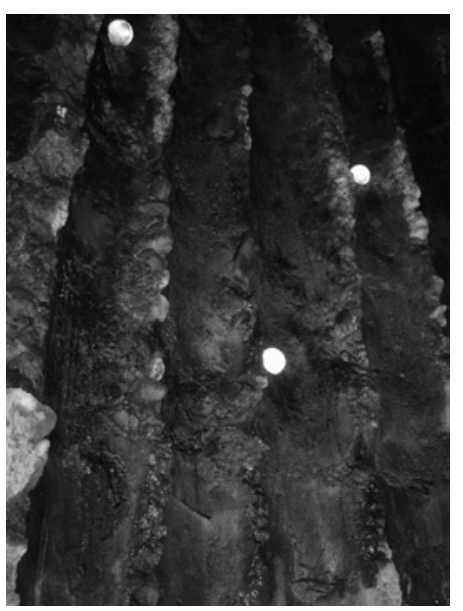

The oozing, dripping and slipping of concrete between the tree trunk formwork" (Photo: author)

11 Zumthor had already remarked: "I think materials somehow stand above form. Artists such as Beuys have used materials in a more essential, basic way than many contemporary architects. There is an unwritten code which defines the meanings of materials in particular contexts and in my buildings I like to work with that." (1996: 64)

12 See Leroi-Gourhan (1943: 14-15.) The idea is developed by Bernard Stiegler (2009: 48-49).

13 Rykwert emphasises that Semper provided four "ways of operating", not four materials. 
14 O.E. dag "dough," from P.Gmc. *daigaz "something kneaded" (cf. O.N. deig, Swed. deg, M.Du. deech, Du. deeg, O.H.G. teic, Ger. Teig, Goth. daigs "dough"), from PIE *dheigh"to build, to form, to knead" (cf. Skt. dehah "body," lit. "that which is formed," dih- "to besmear;" Gk. teikhos "wall;" L. fingere "to form, fashion," figura "a shape, form, figure;" Goth. deigan "to smear;" O.Ir. digen "firm, solid," originally "kneaded into a compact mass".

$15 \mathrm{~J} J \mathrm{~b}, \mathrm{X}, 9-10$. The image of milk clotted by pressure has been used since ancient times. It is a longstanding notion amongst pastoralists of the Pyrenees and Alps to explain the process of conception. See Needham (1959: 64 and 84-5), Belmont (1988:13-28), Didi-Huberman (2008: 54). In Aristotle, the analogy of setting of cheese in the womb to form the baby transmits resemblance. It represented the passage from the liquid phase of seed and blood to the solid phase of the baby's body where the matrix, the womb, was mould - counter-form. De Generatione Animalium (729a).

16 The French, "instinct plastique" [from "Bildungstrieb", a term Hegel borrowed from Johann Friedrich Blumenbach], is usually rendered as "formative-drive" in English.

17 See Legault (2006: 46). Cf. Rudolph's marginal remarks (reported in Pommer 1972: 860): "There is a paradox in the Art and Architecture building - it is relatively carefully built, but the handling of the surfaces renders it purposefully mud."

18 Mud is cognate with and probably from M.L.G. mudde, M.Du. modde "thick mud," from P.Gmc. ${ }^{*} m u d$ - from PIE *meu-/*mu-, found in many words denoting "wet" or "dirty" (cf. Gk. mydos 'damp,' Pol. mul 'slime,' 'Skt. mutra- 'urine,' Avestan muthra- 'excrement, filth'); related to Ger. Schmutz 'dirt,' which also is used for 'mud'.
The word plaster comes from the Greek plássein (whence "plastic") means to mould, stamp, coin, forge, or mass. The last word relates to mássein, to handle, touch, work with the hands, to knead dough, press into a mould. The Latin mas$s a$ is that which adheres together: a lump or mass of pitch, salt, cheese, dough, mud, dirt or air, even. A mass is something of indefinite contour and dimension. The English "glebe" (land, fields; from the Latin gleba: globe, glob, clod or lump of earth) is similar. The etymology of "dough" suggests a history of construction and figuration: figuration by modelling/moulding. ${ }^{14}$ The word "human" derives from humus, earthly being, as opposed to gods' being. In Genesis, man is "formed from the dust of the ground", in Job, moulding is added to modelling:

9. and 10. Remember I beseech thee that thou hast made me as the clay; and wilt thou bring me into dust again? 10 Hast thou not poured me out as milk, and curdled me like cheese ${ }^{15}$

Writing on mud and the primitiveness of the "plastic instinct", Gaston Bachelard quoted Hegel's Philosophy of Nature: "The plastic instinct is like excretion, an act whereby the animal becomes exterior to itself.” $(1947: 106)^{16}$

Some architects, such as Paul Rudolph (whose furrowed, 'corduroy', finish Zumthor's interior resembles), delighted in the plasticity of concrete. "Concrete is mud. I work with concrete, not against it. I like mud", ${ }^{17}$ he jotted, adding, "[o]ne of the most humanising elements in Corbu's concrete is the oozing, dripping and slipping of concrete between poorly placed forms ... " (Pommer 1972: 859) ${ }^{18}$

About the same time, Francis Ponge was composing his "Unfinished Ode to Mud" in which, denying the formation of man from mud, he affirms: "Despised mud, I love you. I love you because people scorn you”, 'concluding' on mud:

But since I am fonder of it than my poem ... I'll give it a chance, not to turn it into words. For it is opposed to forms and remains on the edge of the non-plastic. It tempts us to form, then in the end discourages us. (1999: 729-731, 2009: 80-83)

Ponge's postponement of form, his highly finished 'unfinishedness', is like the highly wrought ooze of concrete within this chapel and the strata without. It is usual to take concrete as an image of solidity, hence the expression 'set in concrete'. But concrete can be worked (as here) in such a way that it leaves traces of its plasticity. Such might be called a 'delay in concrete'. The material and the mud of the fields, masses worked by hand and foot, take form by not taking form. This is the potential of the plastic.

\section{Potentiality}

Plasticity may also be a rendering into material terms. Thus, Max Bill observed of Robert Maillart's bridges that the relationship between the material and the shaping of reinforced concrete is one between "extreme economy" and "spiritually essential purposes".

If we are to call this art "concrete" ["konkret"], because it represents reality, the materialisation of a spiritual idea in the philosophical sense, I would draw attention to the fact that the word "concrete" in Anglo-Saxon terminology has also the meaning of artificially made pourable stone as well as the meaning it has in art; it is material formable after the spirit 
of man by technical means, it is not only similar to stone but possesses still further qualities. Here the circle closes again and the two meanings of concrete do not lie as far apart from each other as one might suppose on hasty comparison. (1949: 31-32)

The emphasis here heads towards the concretisation of an idea: art concret. Another emphasis might see in plasticity a process leaving a trace. Roland Barthes, for example, remarked (somewhat tongue-in-cheek, albeit accurately) that plastic is "a miraculous substance: a miracle is always a sudden transformation of nature. Plastic remains impregnated throughout with this wonder: it is less a thing than a trace of a movement." (1957: 173)

Wright's remark about concrete's "as yet inadequately expressed" aesthetic property implies an element of the unfulfilled. This may be read not only as concrete's potential in modernity, ${ }^{19}$ but also as a figure of potentiality per se that happens to have become emblematic of modernity. Potentiality is usually thought of as a substrate for the actual world, especially in the idea of "development". If potentiality preceded actuality, however, it would be merely something annulled in actualisation. There are, however, ways of thinking the potential outside of futurity's "not yet". What is potential is also not definite enough to be a thing. A differal of form, it is deprived of completed presence. Unfulfilled, it is a trace. The whole interior at Wachendorf is only a trace, by imprint, and smell.

According to Aristotle, "matter is potentiality and form actuality". ${ }^{20}$ Thus, the plastic is both the mouldable and the moulded. It is something on the verge of formlessness: in formation as much as being a form. Bachelard found potentiality in modelling - the moment of making, which entices the material imagination but which, as he noted, is neither fulfilled nor exhausted in completion:

The imagination of forms rests endlessly in repose. Once fulfilled, form is rich in values so objective, so socially exchangeable that the drama of their valorisation slackens. The dream of modelling, on the contrary, is a reverie that maintains its possibilities. (1947: 101-102)

Plasticity, the most common figure of potentiality, concerns the receiving and leaving of traces, aesthectically valued as the inchoate, protean, unfinished and emergent in (post-)modernity. ${ }^{21}$ Reception and passivity are essential elements of concrete's potentiality - like that of clay, wax, or paper before imprinting. But also like the mind, whose relation to the body Aristotle conceived by plasticity: "wax and its imprint" (De Anima, iii 4, 412b 5-7). Furthermore, he conceived the mind as capable of being given, of yielding and suffering form. Similarly, the initial plasticity of concrete is its ability to be moulded into shape: an ability expressed in the passive voice. Concrete's virtue is its passivity.

The potentiality of thought, Aristotle continued, "is like that of the tablet on which there is nothing actually inscribed" (429a 18-24). Here, the unmodelled and untraced are further aspects of the mouldable, which Giorgio Agamben highlights. In relation to plasticity, both the trace and the absence of trace are presences of absence, potentialities. Potentiality is the existence of a non-being, "a form of privation" (Agamben 1999: 179), sterésis, a poverty in which something that is not actual can exist. ${ }^{22}$ Aristotle thus "gives form to an aspect of potentiality that is not reducible to actuality", a potentiality that lives on and "conserves itself in actuality" (184). Here, actuality is no longer simply a using up of potentiality but the full realisation of impotentiality, the potential not to be. Actuality is thus a form of

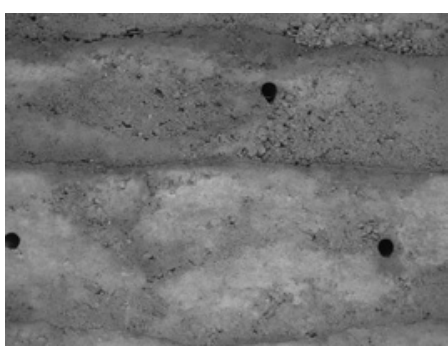

Trampled layers. Photo: Author.

9 Here see (probably the most conspicuous example) Francis Onderdonk: "According to The Esthetics of Potentialities ..., a material approximates perfection in proportion to the number of possibilities it presents. From this point of view ferroconcrete is the most perfect material, as its potentialities far outnumber those of other materials." (1928: 17) Forty complains: "Over and over, people talk about concrete's 'potential,' its 'possibilities' - in other words, it is seen as a material whose existence lies in the future rather than in the present or past." (2006:38)

20 "Estid'he men hule dunamis, to d' eidos entelecheia" (De Anima; iii 4, 412a9). 'Matter' (hule) is that out of which something is made. Entelecheia may be better translated as 'that which has itself in fulfilment' or 'that which has been produced/carried out', as Heidegger (1995: 193) puts it.

21 Cf. Leo Steinberg on Rodin: "His real theme then is the intimacy of gestation, every available means being used to maintain a given figure as a telescoped sculptural process. Whatever vicissitudes a work in progress can undergo are sealed into the form. The wet rags that are wrapped around clay to keep it moist leave their textures imprinted on the bare chest of the great Marcelin Berthelot bust" (1972: 393).

22 Aristotle in Metaphysics writes: "impotentiality (adunamia) is a privation contrary to potentiality. Thus all potentiality is impotentiality of the same with respect to the same." Here Agamben finds the originary structure of potentiality. "All potentiality is impotentiality". The teleological shift from potentiality to actuality becomes the return of potentiality to itself, to its own privation, its own non-being. See also Heidegger (1995: 91-94). 
Darkness: 'the experience of the indeterminate' (Photo: author)
23 According to the Diccionario de la Real Academia Española de la Lengua, hormigón derives from hormigo, which in turn refers to porridges, as lumps or pliant masses, of flour.

24 The process has become celebrated in works such as Bruce Nauman's "A cast of a space under my chair" (1965), Richard Serra's "Casting" (1969), a series of lead angles as both inchoate idea and hardened form (where he threw molten lead into the mould of the juncture of wall and floor in fulfilment of his Verb List Compilation: Actions to Relate to Oneself, 1967-8), and the castings of Rachel Whiteread. For the popularity of direct contact in art practice since the second half of last century, see Didi-Huberman (2008: 327-28). In terms of soot, cf. some of Jannis Kounellis' works "Senza Titolo (Ciminiera)" and "Metamorfosi" in the Hallen für neue Kunst, Schaffhausen, for example.
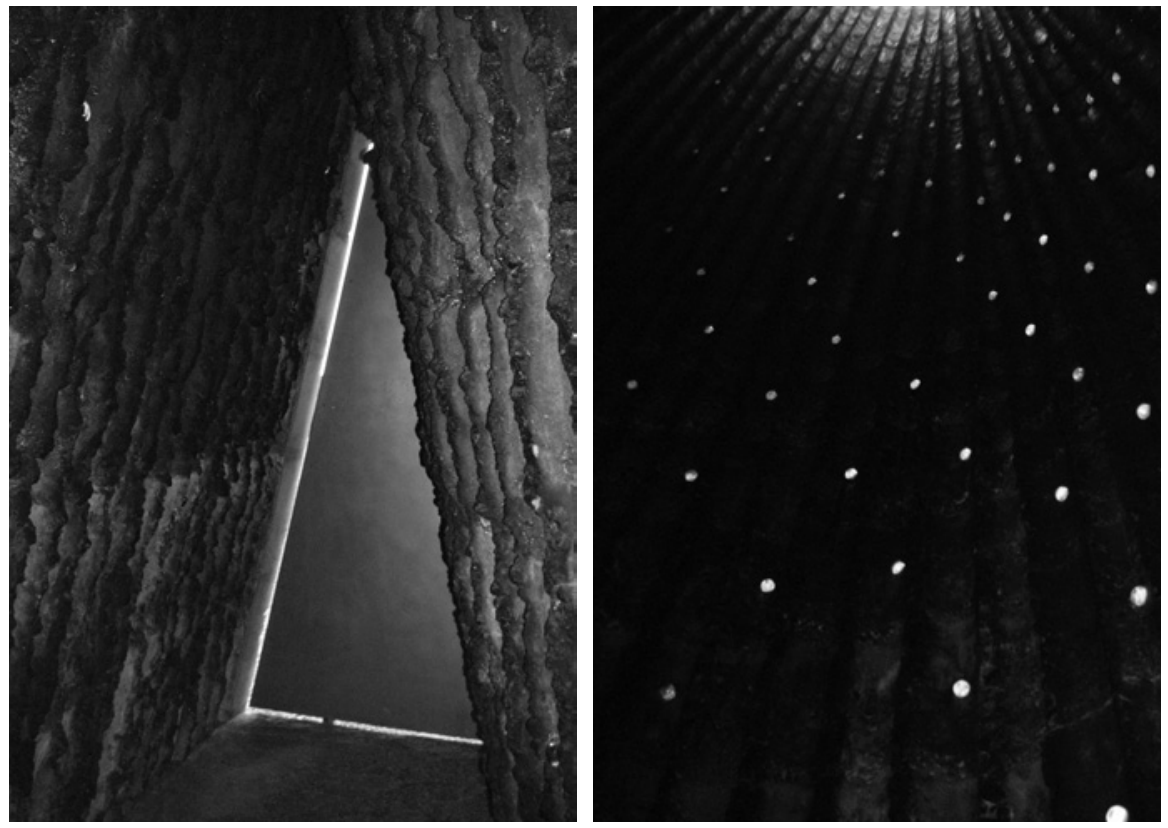

potentiality that is capable of not not being. Matter is not an indeterminate mass or lump before the bestowal of form. It is not "a formless quid aliud whose potentiality suffers an impression”, argues Agamben, "rather it can exist as such because it is the materialisation of a potentiality through the passion (typos, ichnos) of its own impotentiality" (218). Potentiality is on the verge of perceptibility, only an "experience of the indeterminate" makes it possible to think the indeterminate, as in darkness and silence (217).

Inside, this experience of darkness (even by day- or candle-light) and silence (even with cowbells and pilgrims) is what the chapel offers - abundantly. Moreover, it is a measure of Zumthor's craftsmanship, that what he makes here keeps alive the potentiality which is matter, dunamis, the ability to accept and receive form, matter with its making and its making into. The word 'make' (from Proto-Indo European 'mag' - 'to knead, mix, make') is related to 'might', meaning both force (noun) and possibility (verb), as in the Greek, dunamis. The verb 'may', 'to have power' or 'be able, is also cognate with these words. In a sense, all making concerns the forceful change from one state to another. An architecture sensitive to such possibilities, as here, can reveal the 'might' in the making.

\section{Restless containers}

The moulded has neither interior nor inwardness, being but an impression of the exterior of another, "extraneous" (Wright's word) form: its model. It is a cast double that lives vicariously in exchange. What is cast inside at Wachendorf is an exterior, which appears as an interior: outside-in. The word "mould" derives from "model". Similarly flipping in perception and conception since antiquity, the word "form" (forma) has meant both form and formwork. The Spanish and Portuguese words for concrete, hormigón, formigão, allude to this being-given-form. ${ }^{23}$ The Italian and French for cheese, formaggio and fromage, likewise, derive from formare, "to give/be given form". They are made in forms and so-named through impression, that is, represented by the substitution of form by material. The architect Luigi Moretti employed a similar operation to analyse historical interiors, substituting solid for void in cast plaster (Moretti 1952-1953: 9-20,107-108). ${ }^{24}$ 
Reciprocity and reversibility in casting are unsettling, for designer and participant, constituting the restlessness of content and container, donor and recipient, active and passive, male and female. Between them there is always an infinitesimal gap in time and space. Marcel Duchamp understood this well, making a separative difference, tied to the theme of contact and touch, a key part of his "infra-thin (inframince)", for example:

The possible, implying

the becoming - the passage from

one to the other takes place

in the infra-thin. (Duchamp 1983: 1)

Duchamp also describes this "infra-thin" as "[t]he hollows in paper, between the front and back of a thin sheet ..." (Rougemont 1968: 567) It intervenes between mould and casting to affirm their intimacy and separation. In the mould, taking form (invisible and within its own technical system) eludes the operator. As Gilbert Simondon poses the problem, the worker "would have to be able to enter into the mould with the clay, to be made simultaneously mould and clay, to live and experience their joint operation to be able to think taking form in itself." So, it is "the active centre of the technical operation that remains veiled" (Simondon 1989: 243). Because the "'ii]mprinted' form is obtained blindly, in the interiority inaccessible to contact between the substrate-material and its copy in formation" (Didi-Huberman 2008:121), a restless element of contingency, accident, fallibility and chance roam in play. Moulding and casting occur between adventure and anxiety, in an intimacy without interiority.

At Wachendorf, the inside is not only made from an outside but is an outside, being both a (seemingly fortuitous) representation of the radiant firmament (if this can be called 'an outside') and in reality open to the sky with a bowl of rainwater, an impluvium, subtly cast in the floor. The heavens are reflected in a puddle. The jagged ooze of concrete is quite unlike the comfort of any interior. "Outside and inside are both intimate - they are always ready to be reversed ... " as Bachelard proposed relative to subject and world (1957: 196, 1969: 218).

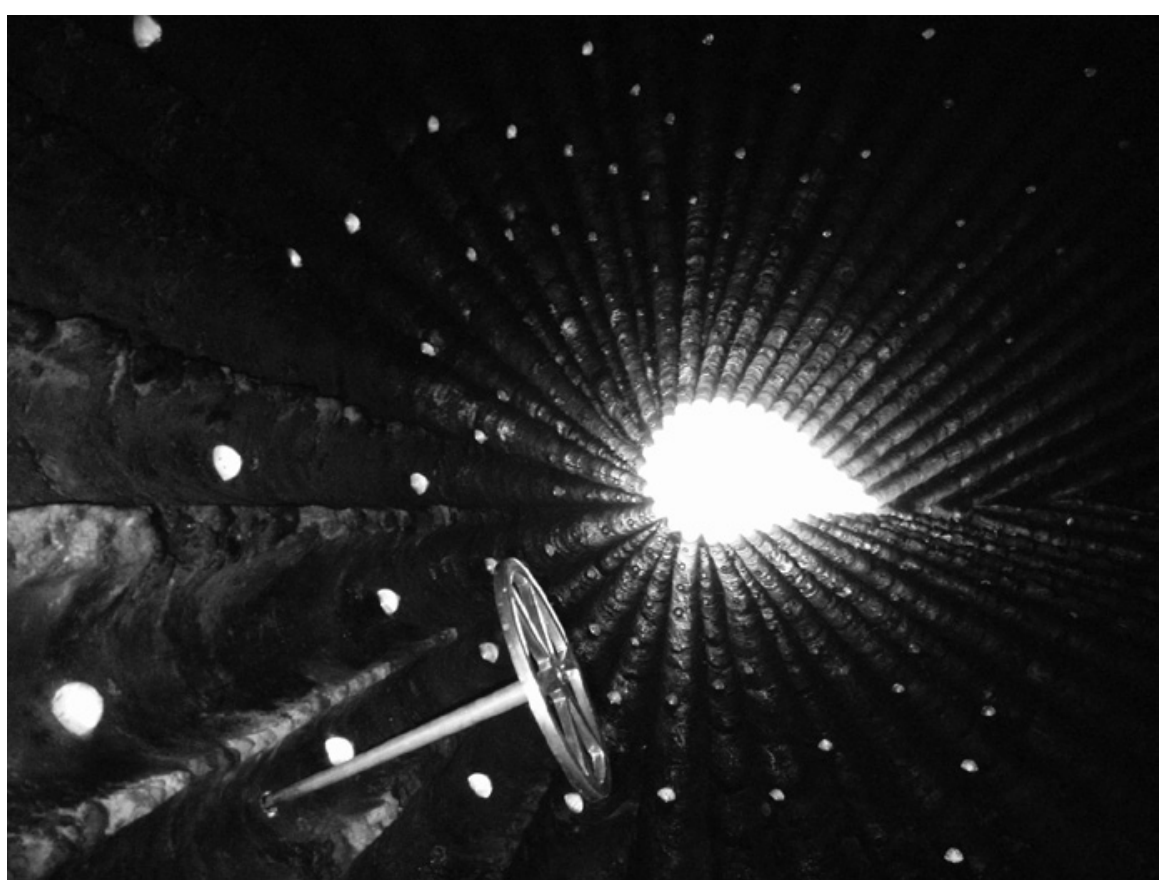

Interior with oculus and 'firmament' of glass tie-plugs. The brass wheel in the likeness of Bruder Klaus' meditation symbol at bottom left. Vestiges of spruce trunks and soot are also visible (Photo: author) 

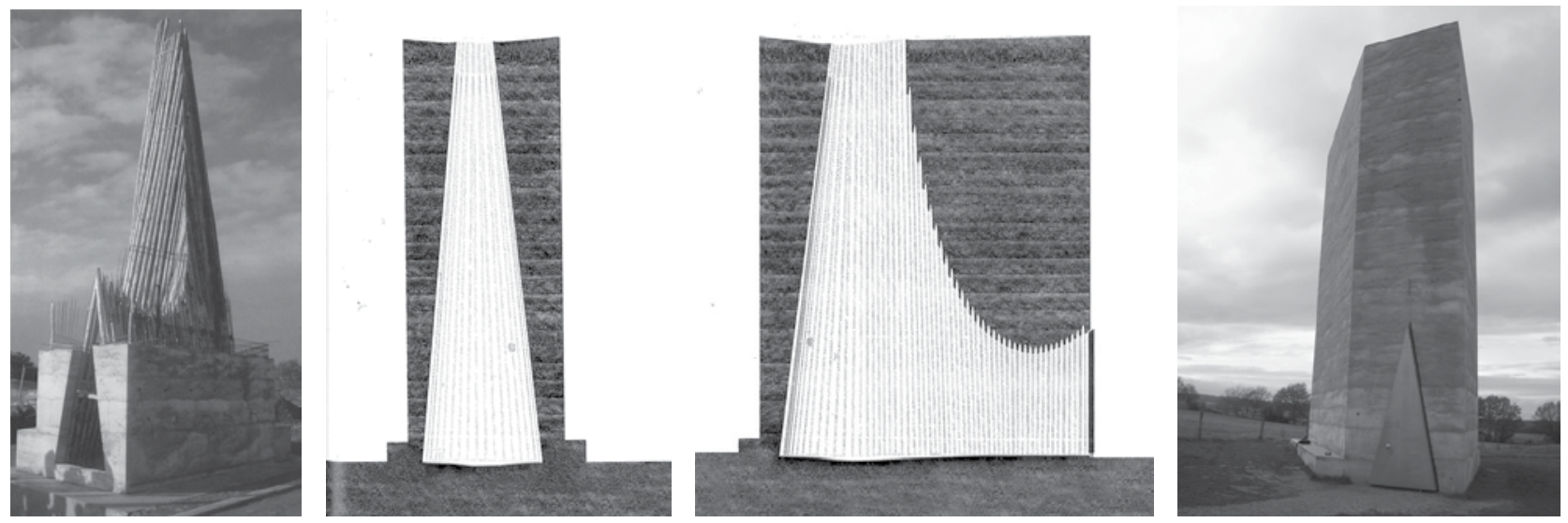

Left: View of chapel under construction showing interior spruce trunk form work (Courtesy Architekturbüro Peter Zumthor), Middle: Cross sections (Courtesy Architekturbüro Peter Zumthor), Right: Strata showing vestiges of successive pours trampled at half metre intervals (Photo: author)

\section{Contact}

What is important in the chapel derives from direct touch with bare material. The result is concrete untreated after removal of the formwork (béton traité 'brut de decoffrage'), in a rough or raw state and bearing the exact imprint of the form into which it had been poured, the mark of making. ${ }^{25}$ As with Corbusier's brute matter, the chapel is something 'as struck', that is, 'as found' after casting. In the post-war period, not only in New Brutalism but also "in Italian Realism or the great engineering structures, reinforced concrete comes with be exhibited as poor material par excellence, which evokes the rudimentary character of the building site" (Poretti 2005: 9). The marks that scar the surface - stigmata - are proof of an authenticity, a striving for purity guaranteed by crudity in the imprint's capacity to register material directly. The words of Philippe Potié on La Tourette are applicable at Wachendorf:

Materials must be displayed in all their poverty in order for them to appear in all their purity. The less a material is worked the more expressive it will be. However, this form of primitivism does not rule out a form of violence which the term Brutalism sums up very neatly ... (2001: 108)

At Wachendorf, 112 spruce trunks (charred and removed) left their traces in the inhospitable interior surface both by imprint and by soot. The imprint's capacity to register things directly in coins, stamps, embossments seals and inscriptions bestows evidence of authenticity. The indexical sign is based on a physical contact to its referent, but one that makes the question of contact rear up into visibility. The inaugural gesture of imprinting, particularly inside the chapel, disorients vision and touch, providing both contact and the look of contact. It questions the tactility of things and materials. ${ }^{26}$

The inanimate imprint is lent a magical animation by that with which it was for a moment in contact and from which it draws its nature as imprint. There is the touch of the formation, then the distance of having been abandoned by what engendered it. What guarantees presence by imprint inevitably states an absence. For the print to be produced the foot must sink into the mud:

the walker must be there, at the very place of the mark to leave it there. But for the imprint to appear in what results, the foot must also lift, be separated ... from then on, quite surely, the walker is no longer there. (Didi-Huberman 2008: 310)

25 See Le Corbusier (1953: 190), Banham (1955: 354-361; 1966: 16), Collins (2004:344) Legault (2006: 47).
The vestige is something physically immediate but temporally remote, a presence as something past. The play of contact and gap overturns our relation to becoming and to memory, "the Now and the Past interweave equally in an unknown and 

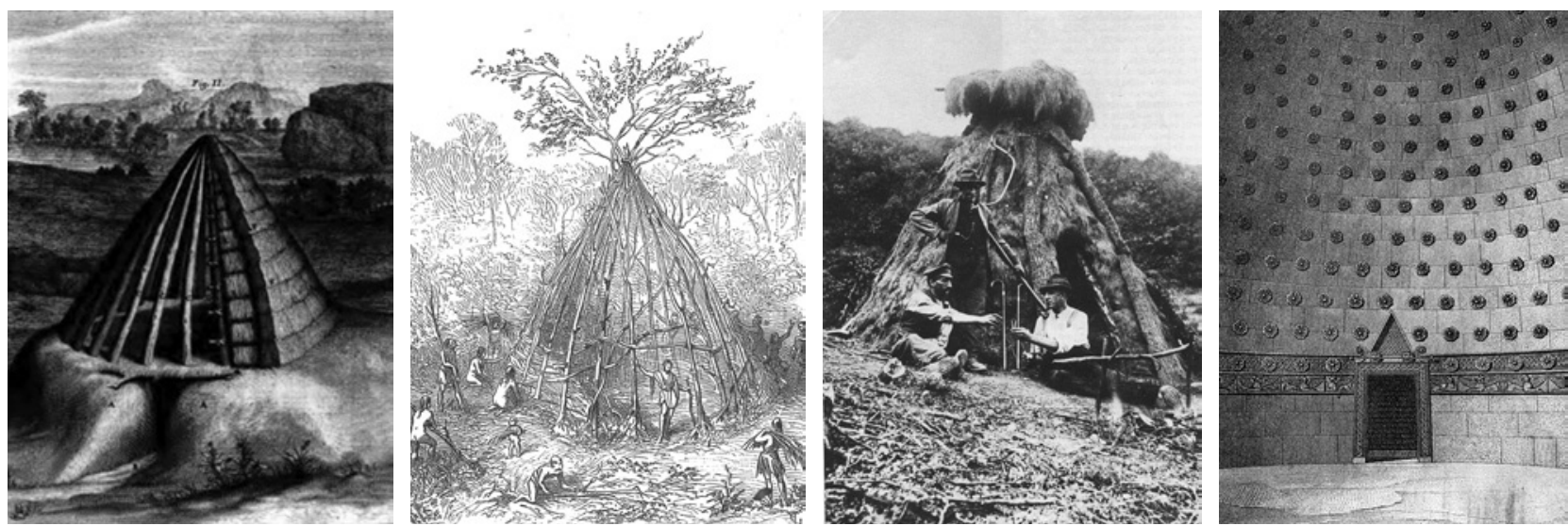

Left to Right: The Primitive Hut (Source: Claude Perrault, Les dix livres d'architecture de Vitruve), The First House (Source: Viollet-le-Duc, The Habitations of Man), Charcoal Kiln or Köhlerhütte, Reconstructional Drawing of a Mycenean Tholos, undated (Source: Anonymous, from Bury, J.B. (1938) A History of Greece).

troubling formation for thought” (310). "[T]he referent 'adheres' to its recording." (Stiegler 2009:14) The reality of the trunks is that of a "having-been-there" - as in a photograph - a borrowed reality, but with "the constantly amazing evidence: this took place in this way" (Barthes 1964: 47). ${ }^{27}$ This play between contact and loss is also that between organic and mineral, living and dead, origin and the putting to death of the origin; between incinerated trunks and fossilised substrate. It is manifest as the lost inner carcass of wicker, straw, or wax in primitive ceramics. ${ }^{28}$ There is another, equally physical vestige (the word meaning "footprint") evident in the building's strata from outside: the concrete, hand-mixed, was tamped, stamped, trampled, trod by the local Land-youth and Land-folk movement in the manner of pisé de terre (rammed earth), in half-metre layers in 24 pours. As with pisé, holes remained through which ties had passed.

What exactly is imprinted inside? Is it a tepee, skéné, the Zelt of which the owners speak (Scheidtweiler 2009), cosmic tent, tabernacle; or a primitive hut (along the lines of Perrault's, Chambers' or Viollet-le-Duc's) - likely home for a hermit; ${ }^{29}$ or a charcoal-kiln (Kohlenmeiler), such as that which provided the mode of releasing the trunks? All three and more, perhaps, a megalithic dromos-tholos schema, something reinforced by the door - symbol of the Trinity or Mycenae? In ichnography, the space suggests a womb. The shapes are unspecific, like the oculus, which in its comma-comet-leaf-tear drop-shape resembles Sogn Benedetg's footprint.

In the mortification of its form by sacrificial fire, the memorial aspect of the chapel emerges: an absence is materialised. This process is an archaism (perhaps a primitivism) but it is not any gratuitous play with history. What this casting depends upon is something rudimentary and anachronistic, an inescapable reference to and employment of an extremely primitive technique, a survival, a living-on, a Nachleben, from a time when humans first made imprints, placed sooty hands on or blew soot over them on cave walls. ${ }^{30}$ Since his presentation-preservation-representation of the Roman remains at Chur, Zumthor's work has posed a question which obliges us to rethink historical knowledge. Rather than striving for any positivist and objectifying certainty, he stages an encounter of temporalities through an 'archaeology' that does not proceed according to plan but shows itself to be "more tactile, more groping, more disturbed, more heuristic", as Didi-Huberman notes of many contemporary works of resemblance by direct contact, imprint and casting (2008: 311).

Stooping into the sudden darkness of Zumthor's chapel on entry, with the imprint of daylight still in the retina, the hand gropes but has little inclination to touch. Here is an experience of inexperience, of the indeterminate, of potentiality in solid and void, of matter made into mass - and space.
27 See also Krauss (1985: 218), DidiHuberman (2008: 189-90)

28 See Leroi-Gourhan (1943: 226).

29 On Nicholas, see Hemleben (1977) Collins (2008)

30 See Didi-Huberman (2008: 27). 
Left: Oldest extant sculpture of Niklaus von der Flüe (Photo: Author, Rathaus Stans)

Right: Sketch Plan (Courtesy Architekturbüro Peter Zumthor)
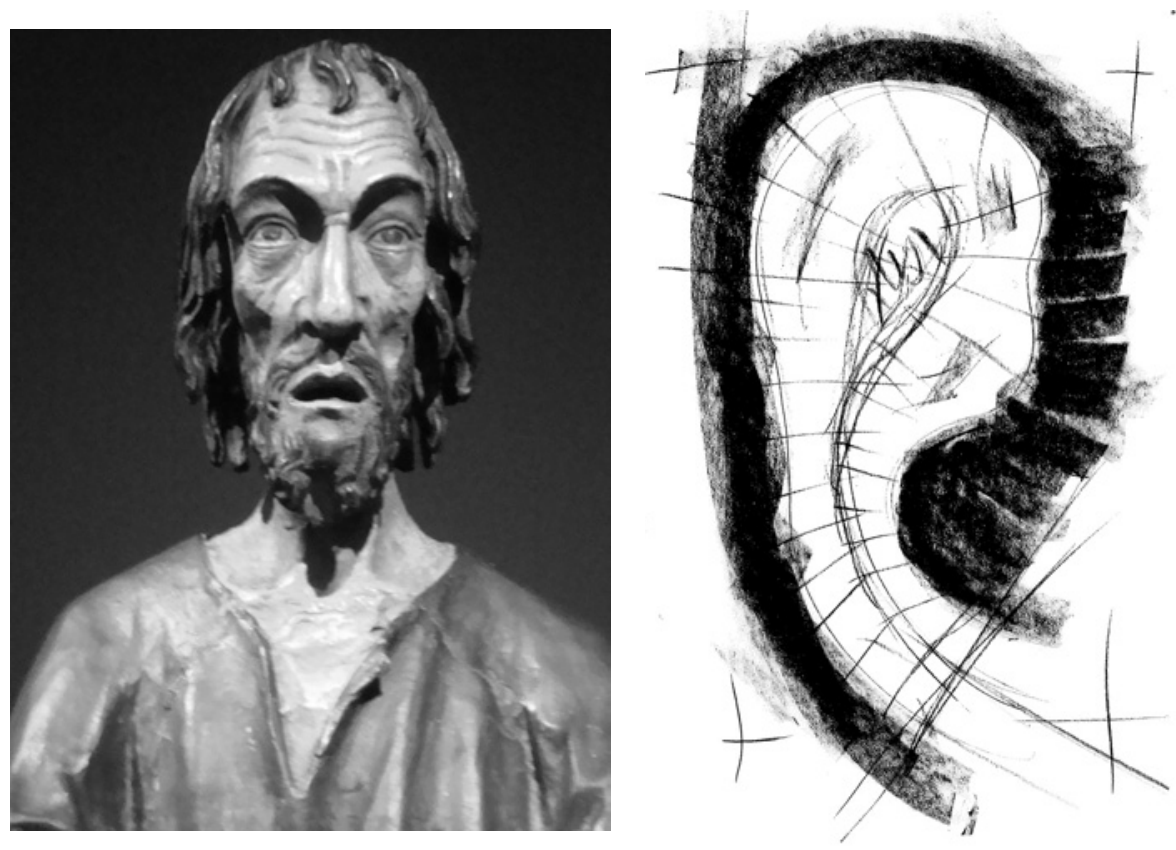

Making

Within the hearth (that is, the interior, here) prevail the crafts of plasticity: the zinc-pewter poured by crucible and flamed by hand over the floor; the breathblown glass stoppers; the half figure of Niklaus cast in bronze (with relic inside); the brass wheel in the likeness of the meditation symbol in his hermitage, the blacksmith's art: the small sacristy shrine and sandbox for the candles, which are of course, also cast.

In all aspects of this constellation, Zumthor articulates relationships between modes of acting on materials and their spare existential properties. When he employs concrete, modern material par excellence, he makes visible what has existed since the 'first' experience of matter and the dialectic between form and formwork, between inside and out. He sets up a structure of preservation based on the persistence of the past in the present. One which may seem fundamentally sparse, hollow, and empty, being a memory in which the past appears as ooze, impression, soot, shade and spectre. All is revealed, if not in a mode of "rescue" (to use a word of Wright's, yet again), then at least in one where nothing is mean or unworthy. The higher poverty of the hermit, an affirmation of autonomous life scarcely comprehensible today, is thrown down as a challenge in silence and darkness.
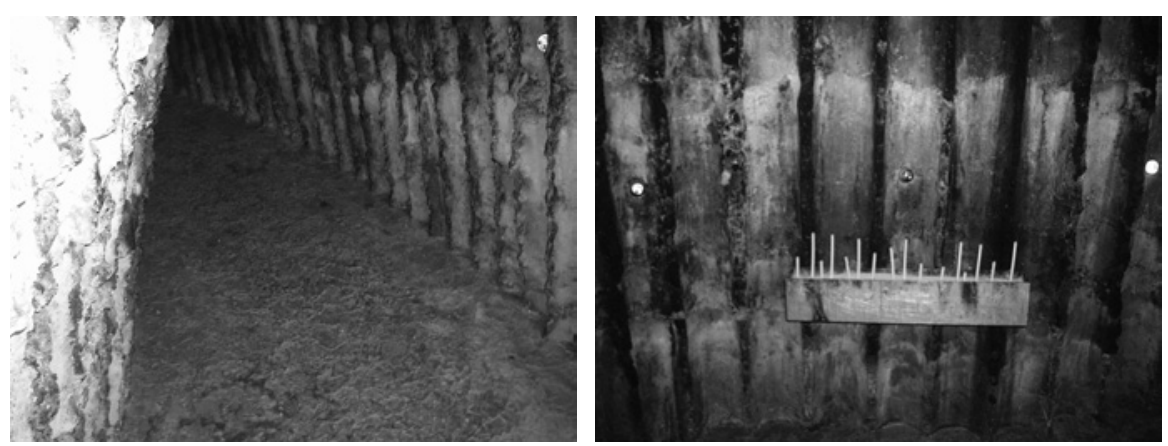

Left: The hand flamed metal floor surface (Photo: author)

Right: The sandbox for the candles (Photo: author) 
The force of the work derives from the relation of materials to context:

I believe they [materials] can assume a poetic quality in the context of an architectural object, although ... materials themselves are not poetic ... Sense emerges when I succeed in bringing out the specific meanings of certain materials in my buildings, meanings that can only be perceived in just this way in this one building. (Zumthor 2006: 8-10)

The chapel demonstrates that significance can lie as much in the very act of making as in any end product. It tests bounds and possibilities in the interplay between bodily actions and the materials of the environment. ${ }^{31}$ The building becomes indistinguishable from the processes that went into its making. It challenges the classical (and current) aesthetic whereby making is 'technique', mere means towards an end called 'form' (or 'image'). Here formation is as important. This may be better rendered in the present participle (forming as opposed to formed, i.e. solidified). Better still, is the notion of the formable, the persisting or 'living-on' of potential inherent in materials. In this field-chapel, Zumthor thickens field and process: setting adheres to setting.

31 In this respect, see Morris (1970).

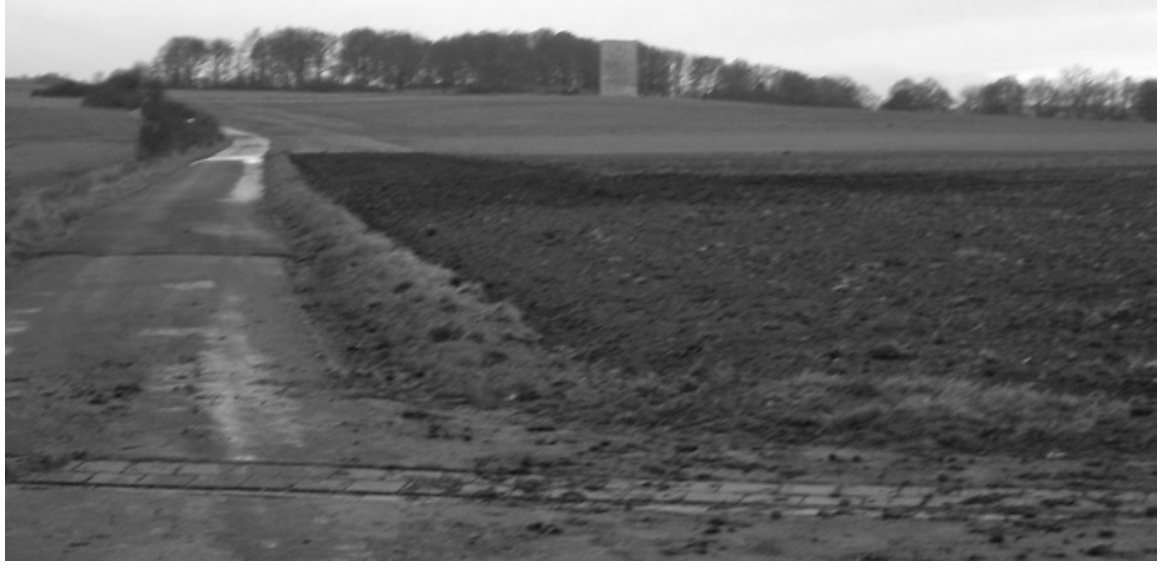

View from distance approaching on foot through fields (Photo: author) 


\section{References:}

Agamben, G. (1999). Potentialities. Collected Essays in Philosophy (D. Heller-Roazen, Trans.). Stanford (CA): Stanford University Press.

Alberti, L. B. (1966). L'Architettura - de re Aedificatoria, ed. Giovanni Orlandi, Milano : II Polifilo, Alberti, L. B. (1988). On the Art of Building in Ten Books (J. Rykwert, Leich, N., Tavernor. R., Trans.). Cambridge (Mass.): The MIT Press.

Aristotle, De Generatione Animalium.

Aristotle, De Anima.

Bachelard, G. (1947). La terre et les rêveries de la volonté. Paris: José Corti.

Bachelard, G. (1957). La poétique de l'espace. Paris: Presses universitaires de France.

Bachelard, G. (1969). The Poetics of Space (M. Jolas, Trans.). Boston: Beacon Press.

Baglione, C. (2007). Peter Zumthor: cappella di Bruder Klaus, Mechernich, Eifel, Germania. Casabella, 71(758), 142-153.

Banham, R. (1955). The New Brutalism. Architectural Review, 118 (December), 354-361.

Banham, R. (1966). The New Brutalism: Ethic or Aesthetic? London: The Architectural Press.

Barthes, R. (1957). Le Plastique. In Mythologies (pp. 170-173). Paris: Éditions du Seuil.

Barthes, R. (1964). Rhetorique de l'image. In Communication, 4: 40-51.

Belmont, N. (1988) L'Enfant et le fromage. L'Homme, 28(105), 13-28.

Benjamin, W. (1980). Erfahrung und Armut. In Gesammelte Schriften I/(1) (pp. 213-219). Frankfurt a.M.: Suhrkamp.

Benjamin, W. (1996) Experience and Poverty. In M. W. Jennings et al. (Eds.), Selected Writings, Vol. 2 (pp. 731-736). Cambridge, Mass.: Belknap Press.

Benjamin, W. (1982). Gesammelte Schriften: Gesammelte Werke Bd 5. Das Passagen-Werk (R. Tiedemann \& H. Schweppenhäuser, Eds.). Frankfurt am Main: Suhrkamp.

Benjamin, W. (1999) The Arcades Project (H. Eiland \& K. McLaughlin, Eds.). Cambridge, Mass.: Belknap Press.

Bill, M. (1949). Robert Maillart: Bridges and Constructions. Erlenbach-Zürich: Verlag für Architektur AG.

Cohen, J.-L. (2006). Modern Architecture and the Saga of Concrete. In Liquid Stone: New Architecture in Concrete (J.-L. Cohen \& G. Martin Moeller, Eds.). New York, N.Y.: Princeton Architectural Press.

Collins, David J (2008). Turning Swiss: The Patriotism of the Holy Hermit Nicholas. Oxford: Oxford University Press.

Collins, P. (2004). Concrete: The Vision of a New Architecture (2nd ed). Montreal: McGill-Queen's University Press.

Didi-Huberman, G. (2008). La ressemblance par contact: archéologie, anachronisme et modernité de l'empreinte. Paris: Minuit.

Duchamp, M. (1983). Notes (P. Matisse, Trans.). Boston: G. K. Hall.

Forty, A. (2006). The Material Without a History. In J.-L. Cohen \& G. Martin Moeller (Eds.), Liquid Stone: New Architecture in Concrete (pp. 34-45). New York, N.Y.: Princeton Architectural Press. Heidegger, M. (1995). Aristotle's Metaphysics 1-3: On the Essence and Actuality of Force. Bloomington: Indiana University Press.

Hemleben, J. (1977). Niklaus von Flüe: der Heilige der Schweiz. Stuttgart: Huber.

Joray, M. (1977). Le béton dans l'art contemporain = Concrete in contemporary art = Beton in der zeitgenössischen Kunst (A. L'Eplattenier-Clapham, Trans.). Neuchâtel: Éditions du Griffon.

Krauss, R. E. (1985). Notes on the Index: Part 2. In The Originality of the Avant-Garde and other Modernist Myths. Cambridge, Mass.: MIT Press.

Le Corbusier (1953). Oeuvre complète, 5 (1946-1952). Zürich: Girsberger.

Legault, R. (2006). The Semantics of Exposed Concrete. In J.-L. Cohen \& G. Martin Moeller (Eds.), Liquid Stone: New Architecture in Concrete (pp. 46-56). New York, N.Y.: Princeton Architectural Press.

Leroi-Gourhan, A. (1943). Evolution et techniques: L'homme et la matière. Paris: A. Michel. Mayer, A.G. (1907). Eisenbauten: Ihre Geschichte und Aesthetik. Esslingen am Neckar: Paul Neff Verlag (reprint 1997, Berlin: Gebrüder Mann Verlag).

Moretti, L. (1952-1953). Strutture e sequenze di spazi. Spazio, 7(December - April), 9-20 and 107-108.

Morris, R. (1970). Some Notes on the Phenomenology of Making: The Search for the Motivated. Artforum VIII(8, April), 62-66.

Needham, J. (1959). A History of Embryology. Cambridge: Cambridge University Press. 
Onderdonk, F. S. (1928). The Ferroconcrete Style. New York: Architectural Book Pub. Co.

Ostler, T. (1995). Building with liquid rock. World Architecture (34), 92-95.

Potié, P.(2001). Le Corbusier: le Couvent Sainte Marie de La Tourette (the Monastery of Sainte Marie de La Tourette). Basel: Birkhauser; Paris: Fondation Le Corbusier.

Pommer, R. (1972). The Art and Architecture Building at Yale once again. The Burlington Magazine, CXIV(837 - December), 853-861.

Ponge, F. (1999). Ode inachevée à la boue. In Oeuvres Complètes Vol. 1 (pp. 729-731). Paris: Gallimard.

Ponge, F. (2009). Unfinished Ode to Mud. (B. B. Brahic, Trans.). London: BC Editions.

Poretti, S. (2005). Il calcestruzzo nelle architetture di Carlo Scarpa. Forme, alterazioni, interventi (G. Bruschi, P. Faccio \& S. P. Maffei, Eds.). Bologna: Editrice Compositori.

Rossmann, A. (2008). Feldkapelle bei Wachendorf = Field chapel near Wachendorf. Detail, 48(12), $12-14$.

Rougemont, D. de (1968). Journal d'un époque (1926-1946). Paris: Gallimard.

Rykwert, J. (1990). Semper's 'Morphology'. Rassegna, XII (41/1 - March), 40-47.

Semper, G. (1879). Der Stil in den technischen und tektonischen Kunsten oder praktische Aesthetik, Vol. 2. München: Bruckmann.

Scheidtweiler, T. \& Scheidtweiler H.-J. (2009). Bau der Kapelle. In Bönsch, M. (Ed.), Zum Himmel Offen: Die Bruder Klaus Kapelle in Wachendorf (unpaginated). Köln: Wüst Rero Service GmbH.

Simondon, G. (1989). Du mode d'existence des objets techniques. Paris: Aubier.

Steinberg, L. (1972). Rodin. In Other Criteria: Confrontations with Twentieth-Century Art (pp. 322403). New York and Oxford: Oxford University Press.

Stiegler, B. (1998). Technics and Time, 1: The Fault of Epimetheus. (R. Beardsworth \& G. Collins, Trans.). Stanford: Stanford University Press.

Stiegler, B. (2009). Technics and Time, 2: Disorientation (S. Barker, Trans.). Stanford: Stanford University Press.

Vitruvius Pollio, Marcus, De Architectura libri decem.

Wright, F. L. (1975). In the Cause of Architecture VII: "The Meaning of Materials - Concrete"

[Architectural Record, August 1928]. New York: McGraw-Hill.

Zumthor, P. (1996). Thermal Baths at Vals. London: Architectural Association.

Zumthor, P. (2006). Thinking Architecture. Basel: Birkhäuser. 